\title{
ANALYSIS OF THE EFFECT OF ENVIRONMENT, FRONTLINE PERSONNEL, MOMENTS OF TRUTH, PRODUCT OFFERINGS ON CUSTOMER LOYALTY THROUGH CUSTOMER EXPERIENCE QUALITY AND RELATIONSHIP QUALITY TO NOBU BANK CUSTOMERS IN SURABAYA
}

\author{
Benedictus Christian Silalahi ${ }^{a *}$, Ronald Suryaputra ${ }^{\mathrm{b}}, \mathrm{Amelia}^{\mathrm{c}}$ \\ ${ }^{a}$ Benedictus.silalahi@gmail.com \\ ${ }^{a}$ Master of Management Student at Pelita Harapan University, Surabaya 60234, Indonesia \\ ${ }^{b, c}$ The Lecturer of Master of Management at Pelita Harapan University, Surabaya 60234, Indonesia
}

\begin{abstract}
The world of manufacturing and services has developed very rapidly from year to year. In the increasingly fierce competition and many rivals in the service world, it encourages every service provider to innovate more. In the development of the service sector in Indonesia, there has been an increasingly tight competition in the banking sector. Banks are business entities that collect funds from the public in the form of savings and distribute them to the public in the form of credit and or other forms in order to improve the standard of living of the people at large (RI Law No.10 / 1998). Nobu Bank is a commercial bank that has been around since 1989 in Indonesia. Therefore, the presence of Nobu Bank was very influential in the development of the banking industry, especially in Surabaya. This study is aimed at analyzing the influence of the environment variables, frontline personnel, moments of truth, and product offerings on customer loyalty through customer experience quality and customer relationship quality of Nobu Bank customers in Surabaya. The sample used in this study is based on data from 125 male and female respondents, domiciled in Surabaya, with an age limit of 18-60 years. The questionnaire was given to respondents who had been Nobu Bank's customers for at least the past 8 years. For processing and analyzing data in this study using SPSS 22.0. Furthermore, to tabulate the results of the respondents' research, as well as to test the research model is to use the Structural Equation Model (SEM) data analysis technique.
\end{abstract}

Keywords: Environment, Frontline Personnel, Moments of Truth, Product Offerings, Customer Experience, Quality, Relationship Quality, Customer Loyalty.

\section{Introduction}

The development in the business world in the current era of globalization is developing very rapidly. The world of manufacturing and services is also experiencing rapid development. Developments in services are also growing from year to year. In the increasingly fierce competition and many rivals in the service world, it encourages every service provider to innovate more. Innovations are made to keep customers.

In the development of the service sector in Indonesia, there has been an increasingly tight competition in the banking sector. A bank is a business entity that collects funds from the public in the form of savings and distributes them to the public in the form of credit and or other forms in order to improve the standard of living of the people at large (RI Law No. 10 of 1998). Banks when facing competition do not only rely on products but also rely on services. This is because there have been many existing banking businesses. Each bank packages products and services to attract consumers (jogloabang.com, downloaded on May 20, 2020).

Based on this, it can be said that a banking business must be able to provide a good service to every customer. This good service can be used as a superior value in facing to survive and grow in existing 
competition. As a form of service that is to provide convenience in transactions. Previously, customers were only able to make transactions by coming to the bank, now an application is available on the cellphone from the bank to check balances to make transactions (aturduit.com, downloaded on May 20, 2020).

Nobu Bank is a commercial bank that has been around since 1989 which previously used the name Bank Alfindo Sejahtera. Currently, Nobu Bank is listed as a BUKU 2 category bank. In 2007 PT Bank National Nobu underwent a name change, which in 2013 became a public company. Bank Nobu is part of the Lippo Group which previously owned Lippo Bank, then currently Lippo Bank has merged with CIMB Niaga. Initially, Nobu Bank only had products such as rupiah savings, rupiah deposits, and credit. After that came other facilities such as ATM cards, Nobu Link, Internet Banking, Mobile Banking, Nobu ePay, Bancassurance, savings in foreign currency. Then for branch offices spread across all regions in Indonesia. There are 112 branch offices and cash offices (nobubank.com, downloaded on 20 May 2020).

As a bank with book category 2, Nobu Bank already has complete facilities in its class. However, Nobu Bank must keep improving in order to survive in the increasingly fierce competitive conditions. It will be an important point to meet consumer needs. Of course, This aims to create more value for the services and products offered so that it can affect the loyalty of customers. To create this value, Nobu Bank can increase environment variables, frontline personnel, moments of truth, and product offerings that result in customer experience quality and relationship quality in order to increase customer loyalty (nobubank.com, downloaded on May 20, 2020).

One of the important factors for service companies to be able to continue running their business is customer loyalty. According to Gibson (2005), customer loyalty is a behavioral drive to make repeated purchases and to build customer loyalty to a product or service produced by this business entity takes a long time through a repetitive purchasing process. Meanwhile, according to Fernandes (2017) Loyalty can be defined as a firmly held commitment by consumers to consistently repurchase preferred products or services in the future, even though the situational influence and marketing efforts of other companies have the potential to cause behavioral shifts.

According to Meyer \& Schwager (2007), customer experience is an internal and subjective customer response as a result of direct or indirect interactions with the company. According to Chen \& Lin (2014), customer experience is a cognitive recognition or perception stimulates customer motivation. Meanwhile, Watkins (2007) defines customer experience as the incarnation of a brand which includes all interactions between organizations and customers.

According to Cetin and Walls (2015), the physical environment includes everything that occurs in response to several stages of the situation, that as a marketer a company needs to provide the right environment and setting for the desired customer experience to emerge. Physical facilities are the basis of all tourism products, because features and hospitality cannot be separated, which include ambience, space / function / amenities, design, and sign / symbol / artifacts.

Tarmoezi (2000) said that the front liner is the front line which is the main activity at the front, and there are staff who make direct contact with the guest (guest contact). The placement of staff at the front must be selective, because they are the ones who will create a first impression for the guests. In the banking world, a frontliner is an employee who serves as customer service and teller. A frontliner in a bank is tasked with assisting customers in making transactions and making a good impression on customers. Frontliners are an important part of the bank. To maintain the quality of each frontliner, at Nobu Bank an assessment is held every month by the head of operations known to the head of the branch, and then it is reported to the special department that deals with service quality (nobubank.com, downloaded on May 20, 2020).

Moments of Truth are various opportunities / interaction meetings that occur between the company and the customer where the customer at that time will experience and provide an assessment of the company's services (Monroe., 2007). Through the moment of truth, it is the process of creating an impressive memory effect that remains in the minds of customers (memorable experience) (Lawrence, 2007).

Product Offerings according to T. Gilarso (2003), the offer is the amount of a certain item that is 
willing to be sold at various possible prices during a certain period of time, ceteris paribus. According to Kotler \& Armstrong(2001), a product is anything that can be offered to the market to get attention, buy, use, or consume that can satisfy consumer wants or needs. Product offering is an existing product offering. In this case, product offering are made from each bank employee so that each product can be recognized by the customer.

\section{Litterature Review}

\subsection{Theories and Hypothesis}

\subsubsection{Environment}

Cetin and Walls (2015: 6), Environment includes everything that occurs in response to several stages of a situation,as a marketer, a company needs to provide the right environment and setting for the desired customer experience to emerge. According to Ma'ruf (2005), the environment of an outlet plays an important role in attracting consumers, making them comfortable in an outlet. The atmosphere referred to is in the sense that the created environment is a combination of elements of shop or outlet design, store planning, visual communication, and marchandising. Determining the design of a shop will create a certain atmosphere known as the environment. Baker (1986) states that the store environment is grouped into ambient factors (music, lighting, smell), design factors (floor covering, wall covering, display / fixtures, color, cleanliness, cellings, dressing rooms, aisles, layout, signs) and social factors (sales people).

Hypothesis 1: Environment has significant effect on the Customer Experience Quality.

\subsubsection{Frontline Personnel}

Tarmoezi (2000) said that the Frontliner is the front line which is the main activity at the front, and there are staff who make direct contact with the guest (guest contact). The placement of staff at the front must be selective, because they are the ones who will create a first impression for the guests. According to Mantel et.al., (2002) Frontline Personnel are part of the objective of implementing various sales strategies carried out between companies and salespeople on an ongoing basis to achieve the expected performance. According to Parasuraman et al (1985) Frontline Personnel are employees or personnel who stand at the forefront of a company who are willing to help customers and provide fast service. This dimension emphasizes attention and accuracy in handling customer requests, questions, complaints, and problems. Responsiveness is communicated to customers the length of time they have to wait for help or answers to questions or attention to problems. Responsiveness also captures ideas about flexibility and the ability to tailor service to customer needs.

\section{Hypothesis 2: Frontline Personnel has significant effect on the Customer Experience Quality.}

\subsubsection{Moments of Truth}

Moments of Truth are various opportunities / interaction meetings that occur between the company and the customer at which time the customer will experience and provide an assessment of the company's services (Monroe et al., 2007). Moment of Truth is a moment of truth that describes the effects of critical factors from a customer experience process in the form of impressive memory effects that make an impression on the minds of customers (Lofgren, 2008). According to Meredith (2006), the Moment of Truth is where there is the creation of a memory effect, namely recalling their experiences, when someone has a reason to join and stay or leave the company. The effect of creation on Moment of Truth is based on meeting process needs between consumers, companies and products with a thorough evaluation. 
Hypothesis 3: Moments of Truth has significant effect on the Customer Experience Quality.

\subsubsection{Product Offering}

Product Offering according to T. Gilarso (2003) is the amount of a certain item that is willing to be sold at various possible prices for a certain period of time. According to Kotler \& Armstrong, (2001: 346) a product is anything that can be offered to the market to get attention, buy, use, or consume which can satisfy the desires or needs of consumers. Product offering is an existing product offering, in this case product offerings are made from each bank employee so that each product can be recognized by the customer. According to Mahardika (in Tjiptono, 2011) a Product Offering is an offer that includes efforts to meet or exceed customer expectations; quality includes products, services, people,processes, and the environment; quality is a condition that is always changing (eg: what is considered quality today may be considered less quality in the future). Hypothesis 4: Product Offering has significant effect on the Customer Experience Quality.

\subsubsection{Customer Experience Quality}

Meyer \& Schwager (2007) states that customer experience quality is an internal and subjective customer response as a result of direct or indirect interactions with the company. According to Gentile, Spiller, and Noci (2007) customer experience quality is derived from a set of interactions between a customer and a product, a company, or part of an organization, which provokes a reaction. This experience is completely personal and implies customer engagement at different levels (rational, emotional, sensory, physical and spiritual). According to Hasan (2013) customer experience quality is the quality of consumer experience with a product that is related to sense (sensory), feel (emotional), think (cognitive), act (action), and relate (relationship) after and before buying the product.

Hypothesis 5: Customer Experience Quality has significant effect on the Relationship Quality.

\subsubsection{Relationship Quality}

Relationship Quality by J. Broc Smith (2013) is defined as a concept that consists of various positive influences caused by a relationship that reflects the overall relationship and the extent of the relationship to the party whose needs and expectations are met. Meanwhile, according to Kumar (1995) Relationship Quality is the highest exchange factor made by buyers to sellers, which is shown by trust, commitment, continuity and the desire to invest the resources owned by the buyer to make a relationship with the seller. Thorsten Et al. (1999) Relationship Quality can be considered as a meta construct consisting of several key components that reflect the overall nature of the relationship between firms and consumers.

Hypothesis 6: Relationship Quality has significant effect on the Customer Loyalty. 


\subsection{Research Model}

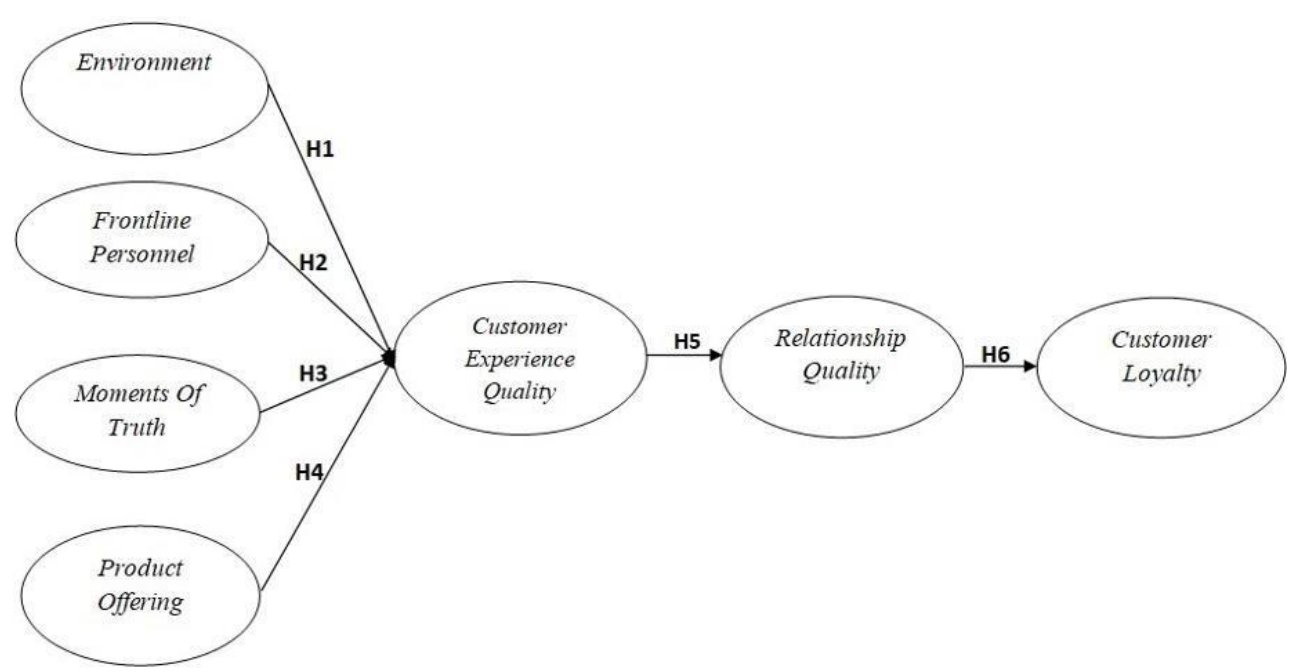

Figure 1: The Framework of Research Model

\section{Research Methods}

This research is causal research, because it is used to develop existing research models to test the research hypotheses that are determined based on literature review to answer the problems identified in the previous chapter. The research method used in this study is a quantitative method, where this method is a scientific approach to managerial and economic decision making. The method used in this study will refer to references that can carry out a simultaneous analysis process associated with a multi-variable research model, the Structural Equation Model (SEM). The program used is the AMOS 22.0 software program. This chapter describes the object of research directed at analyzing models about the relationship between variables to understand the factors that influence Customer Loyalty from Nobu Bank customers in Surabaya. The sampling method used in this research is non- probability sampling. This study uses a questionnaire as the main tool in data collection. In this study, researchers will use a snowball sampling technique, where researchers determine respondents who will help researchers to distribute and fill out questionnaires. The area used as a place for distributing questionnaires was the Surabaya city, so that respondents were selected according to the criteria determined in this study. The characteristics of the respondents determined are men and women aged 18-60 years where the age is an early adulthood (Kotler and Armstrong, 2010), who have become Nobu Bank customers for more than 1 year. There are 24 indicators used in this study. indicators, from the number of existing indicators, the minimum number of samples used is 100-200 respondents, and for this research the number of respondents is 120 people. The sample used for research was 125 respondents. Data collection is done by distributing questionnaires to respondents in accordance with the characteristics of the sample that has been described previously. After completing the questionnaire, the respondent returns the questionnaire that has been filled out and will then be selected by the researcher. The selected questionnaire is a questionnaire that is completely filled out and according to the filling instructions. After selection, the selected questionnaire will be further processed. After the data is tabulated, then the research model will be tested using AMOS software version 22.0. The questionnaire in this study will be divided into two parts. The first part contains questions to get general information about the respondent himself that is useful to determine the suitability of the characteristics of the respondents with the sample criteria. The second part contains 
questions to obtain research data and analyze the effect of Environment, Frontline Personnel, Moments of Truth, Product Offering on Customer Loyalty through Customer Experience Quality and Relationship Quality. The scale used in this study is a Likert Scale, where the answer is provided at intervals from 1=Strongly Disagree (STS) to 5=Strongly Agree (SS). Statements are made using a scale of 1-5 to obtain internal data.

\section{Result and Discussion}

\subsection{Assessment of Measurement Model}

Table 1: Regression Weights Full Structural Equation Model

\begin{tabular}{|c|c|c|c|c|c|}
\hline & Estimate & S.E & C.R. & $\mathrm{P}$ & $\begin{array}{c}\text { Std. } \\
\text { Estimate }\end{array}$ \\
\hline $\begin{array}{lll}\text { Customer } & \text { Experience } & \text { Quality } \\
\text { Environment } & & \\
\end{array}$ & 0,263 & 0,128 & 2,058 & 0,40 & 0,245 \\
\hline $\begin{array}{l}\text { Customer Experience Quality Frontline } \\
\text { Personnel }\end{array}$ & 0,068 & 0,081 & 0,831 & 0,406 & 0,113 \\
\hline $\begin{array}{l}\text { Customer Experience Quality Moments } \\
\text { Of Truth }\end{array}$ & 0,306 & 0,126 & 2,429 & 0,015 & 0,437 \\
\hline $\begin{array}{l}\text { Customer Experience Quality Product } \\
\text { Offering }\end{array}$ & 0,456 & 0,163 & 2,796 & 0,005 & 0,507 \\
\hline $\begin{array}{l}\text { Relationship Quality Customer } \\
\text { Experience Quality }\end{array}$ & 0,984 & 0,229 & 4,294 & $* * *$ & 0,723 \\
\hline Customer Loyalty Relationship Quality & 0,620 & 0,174 & 3,567 & $* * *$ & 0,446 \\
\hline X3Environment & 1,000 & & & & 0,440 \\
\hline X2Environment & 2,098 & 0,867 & 2,420 & 0,016 & 0,915 \\
\hline X1Environment & 1,031 & 0,306 & 3,369 & $* * *$ & 0,404 \\
\hline X6 Frontline Personnel & 1,000 & & & & 0,589 \\
\hline X5 Frontline Personnel & 0,883 & 0,275 & 3,033 & 0,002 & 0,464 \\
\hline X4 Frontline Personnel & 0,785 & 0,276 & 2,850 & 0,004 & 0,589 \\
\hline X9 Moment Of Truth & 1,000 & & & & 0,610 \\
\hline
\end{tabular}




\begin{tabular}{|c|c|c|c|c|c|}
\hline X8 Moment Of Truth & 1,060 & 0,261 & 4,057 & $* * *$ & 0,563 \\
\hline X7 Moment Of Truth & 0,747 & 0,218 & 3,427 & $* * *$ & 0,459 \\
\hline X12 Product Offering & 1,000 & & & & 0,499 \\
\hline X11 Product Offering & 1,536 & 0,355 & 4,328 & $* * *$ & 0,739 \\
\hline X10 Product Offering & 0,923 & 0,245 & 3,763 & $* * *$ & $0,, 531$ \\
\hline Y1 Customer Experience Quality & 1,000 & & & & 0,521 \\
\hline Y3 Customer Experience Quality & 1,332 & 0,260 & 5,120 & $* * *$ & 0,659 \\
\hline Y5 Relationship Quality & 1,000 & & & & 0,629 \\
\hline Y6 Relationship Quality & 1,069 & 0,186 & 5,746 & $* * *$ & 0,701 \\
\hline Y7 Relationship Quality & 1,141 & 0,191 & 5,965 & $* * *$ & 0,675 \\
\hline Y9 Customer Loyalty & 1,000 & & & & 0,690 \\
\hline Y10 Customer Loyalty & 0,947 & 1,137 & 6,903 & $* * *$ & 0,765 \\
\hline Y11 Customer Loyalty & 0,820 & 0,130 & 6,292 & $* * *$ & 0,693 \\
\hline Y2 Customer Experience Quality & 1,451 & 0,271 & 5,360 & $* * *$ & 0,678 \\
\hline Y4 Customer Experience Quality & 1,430 & 0,262 & 5,454 & $* * *$ & 0,747 \\
\hline Y8 Relationship Quality & 0,837 & 0,163 & 5,150 & $* * *$ & 0,578 \\
\hline Y12 Customer Loyalty & 1,036 & 0,142 & 7,280 & $* * *$ & 0,768 \\
\hline
\end{tabular}

Source: Text Output AMOS 22.0 (2020) 


\subsection{Hypotheses Testing}

Table 4: Summary of Testing Results.

\begin{tabular}{|l|c|}
\hline Hypotheses & Analysis \\
\hline H1: Environment has a significant effect on Customer Experience Quality & Accepted \\
\hline H2: Frontline Personnel has a significant effect on Customer Experience Quality & Rejected \\
\hline H3: Moments Of Truth has a significant effect on Customers Experience Quality & Accepted \\
\hline H4: Product Offering has a significant effect on Customer Experience Quality & Accepted \\
\hline H5: Customer Experience Quality has a significant effect on Relationship Quality & Accepted \\
\hline H6: Relationship Quality has a significant effect on Customer Loyalty & Accepted \\
\hline
\end{tabular}

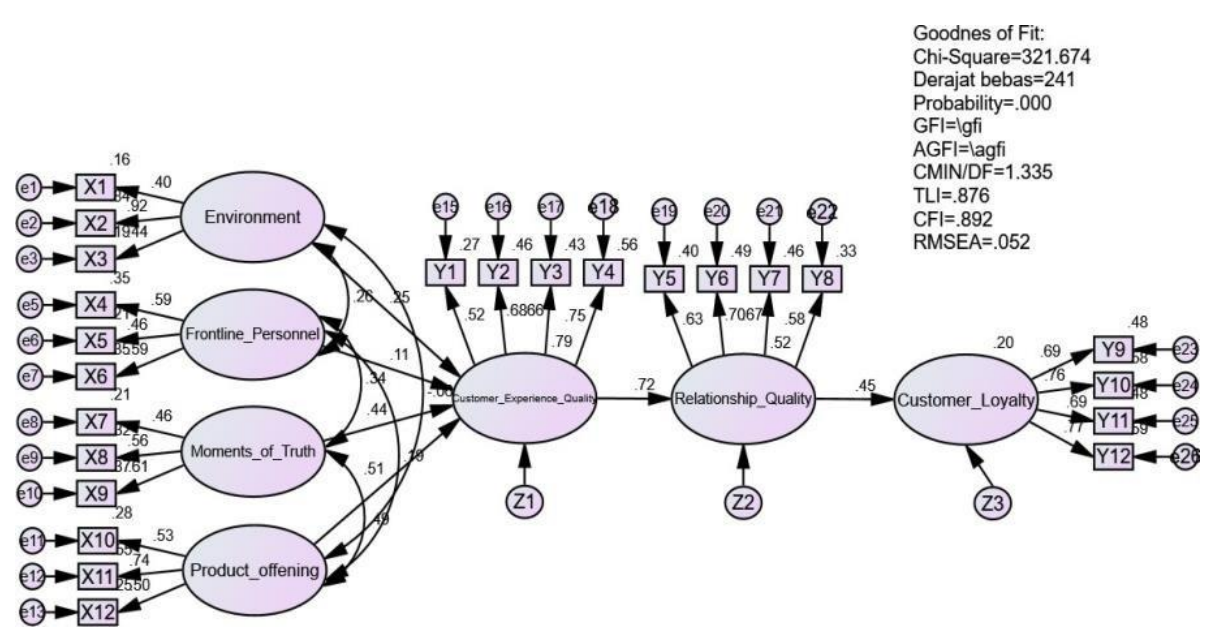

Figure 4.1 Full Structural Equation Model

Source: Amos 22.0 Analysis Result, 2020

\subsection{Discussion}

The results of data processing using AMOS 22.0 software show the six hypotheses proposed in this study. These results can be described as follows, Environment variables have a significant effect on Customer Experience Quality with a C.R value of 2.058 and a regression coefficient of 0.245 ; Frontline Personnel variable has no significant effect on Customer Experience Quality with a C.R value of 0.831 and a regression coefficient of 0.113; the Moments of Truth variable has a significant effect on Customer Experience Quality with a C.R value of 2.429 and a regression coefficient of 0.437 ; Product Offering variable has a significant effect on Customer Experience Quality with a regression coefficient of 0.507 and C.R of 2.796; variable Customer Experience Quality has a significant effect on Relationship Quality with a value of C.R 4.294 and a regression coefficient of 0.723; Relationship Quality variable has a significant effect on Customer Loyalty.

The variable that affects customer loyalty is Relationship Quality with a regression coefficient of 0.446 and C.R of 3.567 which shows a significant positive result. This explains that when you want to increase customer loyalty to Nobu Bank you must pay attention to the comfort with the expertise of each employee, Nobu Bank always tries to provide the best for all its customers, Nobu Bank can provide a sense of security, so that customers can have a sense of trust in the service from Nobu Bank. 
The variable that affects Relationship Quality are Customer Experience Quality with a regression coefficient of 0.723 and a C.R of 4.294 which shows a significant positive result. This explains that when you want to improve Customer Relationship Quality, Nobu Bank must pay attention to the neat appearance of its employees, employees' efforts to make customers happy, employee skills, and employees who are always ready to help customers. To improve this, Nobu Bank can provide training to employees on standards good service, starting with knowing the product in detail, studying the advantages of Nobu Bank's products compared to other banks, to understanding correctly how the problem solving procedure is when a customer has a complaint. Then, employees can also be given friendly service training such as how to greet customers who come by giving a smile and a welcome greeting. Customer experience quality, in the form of the alertness of employees who provide information and help customers when filing complaints, will certainly increase relationship quality in the form of customers getting the expected value so as to attract customers to be more loyal to Nobu Bank.

The variable that affects Customer Experience Quality are Environment, Frontline Personnel, Moment of Truth, and Product Offering. The biggest influence on Customer Experience Quality is Product Offering with a regression coefficient of 0.507 and C.R of 2.796 which shows a significant positive result. This explains that the products offered at Nobu Bank are in accordance with the desires of consumers, because when a customer makes a decision to use Nobu Bank's services, the customer will consider whether Nobu Bank's products are of good quality, for example, such as attractive deposit products for young people, of course this is It must also be supported by good product explanation skills by Nobu Bank employees. This explains that when Nobu Bank wants to improve Customer Experience Quality for customers of Nobu Bank, Nobu Bank must pay attention to information about the latest products properly, always provide products that suit customer needs, and Nobu Bank is always able to offer its products attractively. This is because the majority of respondents in this study are respondents aged 18-35 years where they are concerned with attractive services and attractive transaction offers for them. To increase it, Nobu Bank can provide more products and services such as adding savings products for several vulnerable age existing customers, such as savings for children, savings for teenagers / young people, as well as regular savings categorized as adults. The product offering in the form of product selection and quality product as well as the delivery of employees in offering Nobu Bank products will certainly increase customer experience quality in the form of customers getting the expected value so as to attract customers to be more loyal to Nobu Bank.

The second variable that affects Customer Experience Quality is the Moment of Truth with a regression coefficient value of 0.437 and C.R of 2.429 which shows a significant positive result. This explains that when it comes to improving Customer Experience Quality, Nobu Bank must pay attention to its employees to always respect all customers, the office so that it is easy for customers to find, and focus on solving problems well for customers. To improve it, Nobu Bank can improve its human resources (HR) in this case Nobu Bank employees so that they can solve problems properly, this can be achieved with training conducted by management to improve the quality of existing human resources such as training to improve services Within a period of 6 months that involves all elements of existing employees, Nobu Bank can also add an automatic teller machine (ATM) to make it easier for customers who want to make transactions without having to come to the Nobu Bank office. The moment of truth in the form of employees who respect all customers, an office location that is easy to find, and Nobu Bank, which focuses on solving problems well will certainly improve customer experience quality as customers get the expected value so as to attract customers to be more loyal to Nobu Bank.

The third variable that affects Customer Experience Quality is the Environment with a regression coefficient of 0.245 and a C.R of 2.058 which shows a significant positive result. This explains that the Environment available at the Nobu Bank office is in accordance with the wishes and comfort that customers expect, this explains that when Nobu Bank wants to improve Customer Experience Quality for Nobu Bank, 
Nobu Bank must pay attention to the location of Nobu Bank so that it is easily accessible to customers, such as in several shopping centers. or strategic locations to make it easier for customers to transact, the layout of the rooms at Nobu Bank also needs to be arranged in such a way that customers feel comfortable when they want to make transactions and Nobu Bank's location must be in a safe location. To improve it, Nobu Bank can provide entertainment such as reading materials (books, newspapers, magazines), snacks, drinks or TV viewing while customers are waiting in line with comfortable room conditions for customers. The environment in the form of Nobu Bank's location that is easily accessible to customers, room layout, and Nobu Bank's location which is in a safe location will certainly improve customer experience quality in the form of customers getting the expected value so as to attract customers to be more loyal to Nobu Bank.

The variable that affects Customer Experience Quality are Frontline Personnel with a regression coefficient of 0.113 and C.R of 0.831. This explains that Frontline Personnel do not have a significant effect on Nobu Bank customers. This is because the quality standards of frontline personnel by Nobu Bank when compared to the services of other bank frontline personnel are relatively the same, where frontline personnel service is a general standard in banking companies so this variable is not the main view of customers in assessing Nobu Bank's customer experience quality.

\section{Conclusion}

This model was developed in order to research Nobu Bank's customer loyalty. This research model is formed from the relationship between the influence of the Environment, Frontline Personnel, Moments Of Truth, Product Offerings, on the Customer Loyalty variable through the variable Relationship Quality and Customer Experience Quality. The formulation of the problem in this study is whether the Environment has a significant effect on Customer Experience uality, whether Frontline Personnel has a significant effect on Customer Experience Quality, whether Moments of Truth has a significant effect on Customer Experience Quality, whether Product Offerings has a significant effect on Customer Experience uality, whether Customer Experience Quality has a significant effect on Relationship Quality, and whether Relationship Quality has a significant effect on Customer Loyalty to customers of Nobu Bank in Surabaya. Based on the data processing carried out, the results showed that of the 6 proposed hypotheses, five hypotheses were accepted and one hypothesis was rejected. 


\subsection{Managerial Implications}

Table 5: Managerial Implications

\begin{tabular}{|c|c|}
\hline Current Research & Managerial Implications \\
\hline $\begin{array}{l}\text { Relationship Quality is one element that is the } \\
\text { focus in the process of increasing Customer } \\
\text { Loyalty. }\end{array}$ & $\begin{array}{l}\text { - Give prizes in the form of hempers or other prizes, to } \\
\text { customers who have passed special criteria. For example, if } \\
\text { a customer keeps a deposit of } 500 \text { million, then Nobu Bank } \\
\text { will give hempers for the customer's holiday. This is quite } \\
\text { important in maintaining good relations between Nobu } \\
\text { Bank and customers. } \\
\text { - Ensuring data security, as well as offering security } \\
\text { guarantees to customers. In providing a sense of security for } \\
\text { customers, it is important for Nobu Bank to maintain its } \\
\text { commitment to data security by implementing adequate } \\
\text { physical, electronic and management measures in } \\
\text { safeguarding and securing customer personal data, where } \\
\text { Nobu Bank can upgrade the site security area that supports } \\
\text { the use of protocols. Secure Socket Layer (SSL) and } 128- \\
\text { encryption technology which is encryption on the Internet in } \\
\text { protecting customer data. Also by protecting the Nobu } \\
\text { Bank web servers behind "firewalls" and constantly } \\
\text { monitoring the system to prevent unauthorized access. } \\
\text { However, Nobu Bank must also be ready to offer } \\
\text { guarantees in the event of something untoward such as data } \\
\text { breaches. } \\
\text { - Give appreciation / reward in the form of employee of } \\
\text { the month to employees. Employee of the month is an } \\
\text { award to employees who have the best performance for the } \\
\text { month, this award gives remuneration for employee } \\
\text { performance achievement, on the other hand, employees } \\
\text { who get this award will feel proud and appreciated because } \\
\text { their hard work is noticed by the company. This award aims } \\
\text { to encourage employees to always produce the best } \\
\text { performance performance so that service to customers is } \\
\text { expected to result in comfortable yet professional service. }\end{array}$ \\
\hline
\end{tabular}


Customer Experience Quality is one of the elements that is the focus of the process to improve Relationship Quality.
- Increase the good relationship with customers using social media such as Whatsapp, Instagram, Facebook, or Line so that when customers need help, Nobu Bank employees who have established good relationships with customers can readily help with customer problems, so customers don't have to come directly to ask for a way out of the problem. In addition, Nobu Bank can conduct morning briefs every morning, which aims to serve as reminders to employees to understand what the company's targets are, with a defined vision where Nobu Bank highly upholds customer trust and satisfaction, as well as so that employees prioritize company interests rather than self-interest, so that the actions taken by Nobu Bank employees in serving customers can generate a sense of comfort and pleasure for customer trust and satisfaction.

- Conduct various stages of training for employees. For a banking company that focuses on customers, employee expertise is important, therefore it is important for Nobu Bank to carry out various stages of training for employees. This training is carried out when employees are about to work, until when they become permanent employees by creating an annual program where every year Nobu Bank employees are required to take part in training aimed at improving their abilities and skills. It is hoped that through this training, Nobu Bank can produce expert and professional employees who can master and understand how to handle customers well. In order for this to be achieved, Nobu Bank needs to further tighten the employee selection process in order to have more competent employees.

The Product Offering is one element that is the focus of the process to improve customer Experience Quality.
- Providing innovative savings products for several age ranges of existing customers, such as savings for children, savings for adolescents / young people, and ordinary savings categorized as adults.

- Presenting attractive promotions as an important means of communication for the wider community to become Nobu Bank customers. One of the promotions that can increase brand popularity and is expected to influence Nobu Bank's sales is to use brand ambassadors. Wearing brand ambassadors is a positive trend that Nobu Bank can use to attract the attention of the wider community. With the help of good and trusted brand ambassadors, Nobu Bank is able to attract public trust, which is an important factor in banking companies.

- Improve and maintain existing performance again in terms of solving existing problems, one example that Nobu 


\begin{tabular}{|c|c|}
\hline customer Experience Quality. & $\begin{array}{l}\text { bank can do is to improve existing human resources so that } \\
\text { they can solve problems properly, this can be achieved with } \\
\text { training conducted by management to improve the quality of } \\
\text { existing human resources. } \\
\text { - Adding an automatic teller machine (ATM). The main } \\
\text { function of an ATM is to make it easier for customers who } \\
\text { want to withdraw or deposit money immediately and } \\
\text { practically without having to go to the bank office. } \\
\text { Therefore, the existence of Nobu Bank ATMs is a factor to } \\
\text { consider so that customers can easily reach ATMs, } \\
\text { considering that Nobu Bank in Surabaya only has two } \\
\text { ATMs. In addition, Nobu Bank can provide a cash deposit } \\
\text { machine that can make it easier for customers who want to } \\
\text { deposit money into a personal savings account or send it to } \\
\text { someone else's account, this can save customers time } \\
\text { compared to having to deposit money through a bank teller. }\end{array}$ \\
\hline $\begin{array}{l}\text { Environment is one of the elements that is } \\
\text { the } \\
\text { focus in the process to improve } \\
\text { Customer Experience Quality }\end{array}$ & $\begin{array}{l}\text { - Renewed customer waiting room comfort. A } \\
\text { magnificent bank office, clean bank office, cool wall paint } \\
\text { and a comfortable waiting room because the air conditioner } \\
\text { is functioning properly will invite customers to come and } \\
\text { transact comfortably. Nobu Bank can provide shelves of } \\
\text { reading books or daily newspapers for customers to read } \\
\text { while waiting to make transactions. Existing facilities must } \\
\text { be monitored every day, whether they meet the } \\
\text { measurement indicators periodically such as, are the } \\
\text { brochure shelves, books, newspapers filled and tidy? Are } \\
\text { the toilets clean?, etc. If this is observed and implemented } \\
\text { by Nobu Bank so even long queues will not be a problem } \\
\text { for customers. } \\
\text { - Adding branch offices in the Surabaya area } \\
\text { considering that Nobu Bank only has one branch office and } \\
\text { one cash office in Surabaya. The existence of branch offices } \\
\text { is required to provide banking services that cannot be done } \\
\text { by ATM machines or digitally (internet banking and mobile } \\
\text { baking), such as large transaction services to account } \\
\text { opening services. Therefore this is important so that the } \\
\text { Nobu Bank office is close and easily accessible to } \\
\text { customers. }\end{array}$ \\
\hline
\end{tabular}


Frontline Personnel is one element that is the focus of the process to improve Customer Experience Quality.
- Conduct training for employees on the details of Nobu Bank products. Apart from that, routine training can also be conducted on the advantages of Nobu Bank's products compared to similar products at other banks. That way, employees can have extensive knowledge and will also always be up to date on similar products at other banks so that employees are able to convince customers to use Nobu Bank's services and can consult which products are suitable for customers. This is important to do, because sometimes, many employees seem less responsive in serving customers who like to compare with the similar products.

- Providing communication applications, where customers who need assistance but are unable to come to the Nobu Bank office can be served by customer service that is available 24 hours.

\subsection{Recommendation}

Seeing the results of existing research where there are still many limitations on the research conducted by the author, recommendations that can be submitted by the author are as follows:

- Recommend Nobu Bank to develop a product offering, for example by providing innovative savings products for various age ranges of existing customers, such as savings for children, savings for teenagers / young people, and ordinary savings categorized as adults.

- Seeing the limitations regarding the research object that only takes respondents, namely Nobu Bank customers, it is hoped that the next research using the same or modified model can be applied to different objects to obtain more general results on the factors that affect Customer Loyalty.

- Further research is expected to complement the existing variables in this study so that it can further enhance the understanding of the factors that influence Customer Loyalty, such as brand image, manufacturing quality and word of mouth.

- Further research can be developed by linking the factors that influence Customer Loyalty based on Customer Experience. Future research can also expand the scope of respondents to be researched, or conduct the research in a different area from the current research. So that the further research carried out provides a broad picture of Customer Loyalty.

- In addition, it is hoped that the structural equational model (SEM) can be used but by using the Lisrel software in future research.

\section{References}

Gilarso, T. SJ.(2003).Pengantar ilmu Ekonomi Mikro. Penerbit Kanisius. Yogyakarta.

Kumar, N., Scheer, L. K., \& Steenkamp, J. B. E. (1995). The effects of perceived interdependence on dealer attitudes. Journal of marketing research, 32(3), 
Löfgren, M., \& Witell, L. (2008). Two decades of using Kano's theory of attractive quality: a literature review. Quality Management Journal, 15(1), 59-75.

Ma'ruf, J. J., Mohamad, O., \& Ramayah, T. (2005). Intention to purchase via the internet: a comparison of two theoretical models.Asian Academy of Management Journal, 10(1), 7995 .

Meredith, M. (2006). The state of Africa: a history of fifty years of independence.

London, The. Meyer, C., \& Schwager, A. (2007). Understanding customer experience. Harvard business review,85(2), 116.

https://www.jogloabang.com/pustaka https://www.aturduit.com/articles/panduan-perbankan/jasa-

dan-layanan-bank/

\section{APPENDIX}

TABLE: The Items List Used in the study

\begin{tabular}{|c|}
\hline Variable Customer Experience Quality \\
\hline $\begin{array}{l}\text { Y1: In my opinion, Nobu Bank employees have a neat appearance } \\
\text { Y2: In my opinion, Nobu Bank employees always try to make customers happy } \\
\text { Y3: In my opinion, Nobu Bank employees are very well trained } \\
\text { Y4: I feel that Nobu Bank employees are always ready to help me well }\end{array}$ \\
\hline Variable Relationship Quality \\
\hline $\begin{array}{l}\text { Y5: I feel comfortable with the expertise of each employee } \\
\text { Y6: I feel that Nobu Bank always tries to provide the best for all of its customers } \\
\text { Y7: I feel Nobu Bank can provide a sense of security } \\
\text { Y8: I believe in the services of Nobu Bank }\end{array}$ \\
\hline Variable Customer Loyalty \\
\hline $\begin{array}{l}\text { Y9: I will do more transaction activities with Nobu Bank } \\
\text { Y10: I will recommend Nobu Bank products to my family and friends } \\
\text { Y11: I will say positive things about Nobu Bank's products to others } \\
\text { Y12: I consider Nobu Bank to be the best choice of bank }\end{array}$ \\
\hline Variable Environment \\
\hline $\begin{array}{l}\mathrm{X} 1 \text { : In my opinion, the location of Nobu Bank is easy to reach. } \\
\mathrm{X} 2 \text { : In my opinion, the room layout at Nobu Bank is comfortable } \\
\mathrm{X} 3 \text { : In my opinion, Nobu Bank is in a safe location }\end{array}$ \\
\hline Variable Frontline Personnel \\
\hline $\begin{array}{l}\text { X4: In my opinion, Nobu Bank employees are friendly } \\
\text { X5: In my opinion, Nobu Bank employees always try to help well } \\
\text { X6: I feel that Nobu Bank employees are good at the product }\end{array}$ \\
\hline Variable Moment of Truth \\
\hline
\end{tabular}


X7: I feel that Nobu Bank always appreciates all of its customers well X8: I feel that Nobu Bank is easy to find

X9: I feel that Nobu Bank focuses on problem solving well

Variable Product Offering

X10: Nobu Bank always provides good information about the latest products

X11: I feel Nobu Bank always provides a product that suits my needs

X12: I feel that Nobu Bank is always able to offer its products in an attractive manner 